\title{
Funkcje białek Rab w roślinach - na poziomie komórki i organizmu
}

\section{Małgorzata Gutkowska ${ }^{\varpi}$, \\ Marta Hoffman-Sommer, \\ Paweł Jakub Kubski}

Instytut Biochemii i Biofizyki PAN, Warszawa

https://doi.org/10.18388/pb.2021_368

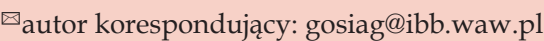

Słowa kluczowe: białka Rab, transport pęcherzykowy, roślina, Arabidopsis

Wykaz skrótów: GAP (GTPase- Activating Protein), GDF (GDI-Displacement Factor), GDI (Guanine-nucleotide Dissociation Inhibitor), GEF (Guanine nucleotide Exchange Factor), REP (ㅈab Escort Protein), RGT (ㅈab Geranylgeranyl Transferase)

\section{STRESZCZENIE:}

B iałka Rab są niezbędne w procesach fuzji i pączkowania błon i w związku z tym są kluczowe dla regulacji transportu wewnątrzkomórkowego w komórkach eukariotycznych. Białka Rab mają też wpływ na wiele innych aspektów funkcjonowania komórek, takich jak rearanżacje cytoszkieletu, wyznaczenie polarności komórki czy przekazywanie sygnałów. Białka Rab oddziałują tu zarówno pośrednio, poprzez swój wpływ na dostarczanie odpowiednich białek i polisacharydów do ich miejsc docelowych w komórce, jak i bezpośrednio, poprzez białka efektorowe. Konsekwencje zaburzeń $w$ funkcjonowaniu białek Rab można obserwować na wszystkich poziomach działania organizmu - od komórek przez tkanki i organy aż po cały organizm. U roślin procesy zależne od białek Rab są istotne dla architektury komórki, jej różnicowania, reakcji na stres biotyczny i abiotyczny, a także dla wydajności produkcji rolniczej.

Białka Rab należą do nadrodziny małych GTPaz, kluczowych regulatorów wielu procesów w komórkach eukariotycznych: przede wszystkim wewnątrzkomórkowego transportu pęcherzykowego, ale pośrednio też rearanżacji cytoszkieletu, wyznaczania polarności komórki czy przekazywania sygnału. Jako pierwsze spośród małych GTPaz scharakteryzowane zostały białka Ras, których mutacje często prowadzą do powstawania nowotworów u ludzi. Nieco później zidentyfikowano białka podobne do białek Ras, ale zaangażowane w procesy transportu wewnątrzkomórkowego. Pierwsze zostało opisane białko Ypt1p z drożdży, potem podobne białka zidentyfikowano w komórkach zwierzęcych i to od nich pochodzi nazwa Rab (ang. Ras-like proteins from rat brain). U drożdży zidentyfikowano ostatecznie 11 białek Rab, natomiast u zwierząt i roślin białka Rab tworzą znacznie liczniejsze rodziny. W komórkach ludzkich znamy obecnie 63 białka Rab, a w komórkach Arabidopsis thaliana zidentyfikowano 57 genów, kodujących prawdopodobnie 54 funkcjonalne białka [1-3].

Białka Rab, aby mogły pełnić funkcje w powstawaniu i kierowaniu pęcherzyków transportowych do odpowiednich przedziałów komórkowych, muszą być zakotwiczone w błonach biologicznych. Możliwe jest to dzięki kowalencyjnemu dołączeniu grup lipidowych. Zazwyczaj dwie C-końcowe reszty cystylowe w białku modyfikowane są resztami geranylogeranylowymi, choć znane są też nieliczne białka Rab, które są wyłącznie palmitoilowane. Proces geranylogeranylacji katalizuje enzym RGT (ang. ㅈab Geranylgeranyl Transferase) z udziałem białka pomocniczego REP (ang. Rab Escort Protein). Cząsteczka białka REP eskortuje czyli przenosi (stąd nazwa) lipidowane białka Rab do błony [3]. Z kolei nieaktywne białka Rab są usuwane z błon przez białka GDI (ang. Guanine-nucleotide Dissociation Inhibitor) (Ryc. 1), które pozwalają przenieść cząsteczkę Rab do cytoplazmy. Natomiast z powrotem do błony białka Rab trafiają dzięki białkom GDF (ang. G DI-Displacement Factor), które uwalniają Rab-GDP z kompleksu z GDI i tym samym odsłaniają oddziałujące z błoną grupy lipidowe. Nieaktywna forma Rab-GDP pozostaje zatem w równowadze pomiędzy błoną (z którą oddziałuje za pomocą kowalencyjnie przyłączonych reszt geranylogeranylowych) a cytoplazmą (w kompleksie z białkami REP lub GDI, które maskują obecność grup lipidowych). W postaci związanej z błoną Rab-GDP jest dostępne dla białek GEF (ang. Guanine nucleotide Exxchange Factor), które katalizują wymianę GDP na GTP i tym samym aktywują białko Rab. Aktywne Rab-GTP związane na powierzchni dwuwarstwy lipidowej może oddziaływać ze zlokalizowanymi w tych samych domenach błonowych białkami efektorowymi [1,2]. Wśród efektorów Rab znajdują się białka zaangażowane w tworzenie lub odpączkowywanie pęcherzyków transportowych (np. białka płaszcza), ruch pęcherzyków (np. białka motoryczne) i fuzję pęcherzyków z błonami docelowymi (np. białka SNARE). Wśród efektorów Rab jest także wiele enzymów (białka Rab regulują bezpośrednio np. aktywność kinaz fosfoinozytoli, których produkty lipidowe zwiększają płyn- 


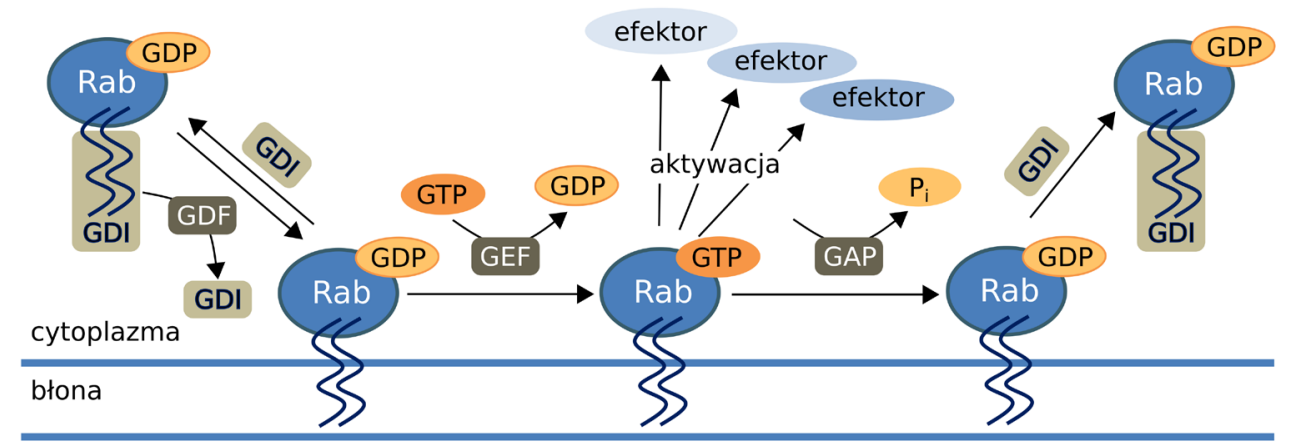

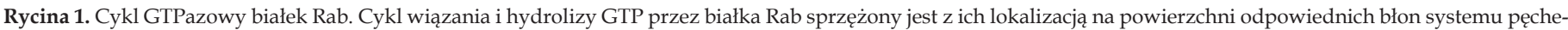

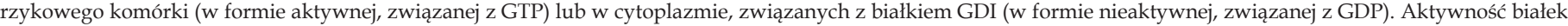
zwiększających lub hamujących prędkość hydrolizy GTP do GDP i oddysocjowania nukleotydu ma wpływ na lokalizację białek Rab.

ność i fuzjogenność błon). Białko Rab pozostaje aktywne do czasu, gdy związana cząsteczka GTP nie ulegnie hydrolizie do GDP. Hydrolizę GTP do GDP i dezaktywację białek Rab

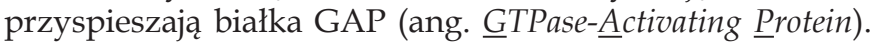
Błonowe Rab-GDP może zostać ponownie usunięte $\mathrm{z}$ błony przez GDI, co zamyka cykl aktywności zależny od wiązania nukleotydu $[1,2]$. Ten mechanizm pozwala komórce wykorzystywać białka Rab do regulacji wielu białek efektorowych.

\section{KOMÓRKA ROŚLINNA VERSUS ZWIERZĘCA}

Aby dobrze zrozumieć, jak objawiają się dysfunkcje białek Rab w roślinach, warto przypomnieć, że różnice między roślinami a zwierzętami dotyczą organizacji nie tylko na poziomie tkanek i organów, ale także na poziomie pojedynczych komórek.

Kluczowa z punktu widzenia organizacji transportu wewnątrzkomórkowego jest obecność u roślin ściany komórkowej. Struktura ta, zbudowana głównie z celulozy, ale też i innych polisacharydów, otacza komórki roślinne oraz jednocześnie stanowi barierę dla transportu między nimi. Sztywna ściana ogranicza też zmiany kształtu komórki. Większość komórek roślin ma kształt prostopadłościanów. Wraz ze wzrostem komórki ściany komórkowe także muszą rosnąć i to w sposób nierównomierny. Na przykład tam, gdzie komórki wydłużają się, poszczególne ściany otaczające komórkę są nierównocenne: ściany górna i dolna nie powiększają swojej powierzchni, w przeciwieństwie do ścian bocznych. Dodatkowo krawędzie i narożniki prostopadłościanu stanowią odrębne domeny ściany komórkowej i zachowują się odmiennie niż płaszczyzny boczne [4]. Rośliny mają też wyraźnie wyznaczoną główną oś wzrostu góra-dół, dzięki odbieraniu bodźców grawitacyjnych (dół) i światła słonecznego (góra). Z tej przyczyny ściany i błony, górna i dolna, poszczególnych komórek nie są takie same. Przypomina to sytuację wyspecjalizowanych komórek $\mathrm{w}$ tkankach nabłonkowych zwierząt, w których komórki mają inną budowę od strony wewnętrznej, a inną od strony zewnętrznej organu.

W przeciwieństwie do komórek zwierzęcych komórki roślinne zachowują natomiast ciągłość cytoplazmy w tkance. Dzieje się tak, ponieważ ściany komórkowe roślin poprze- cinane są plazmodesmami, otworami o regulowanym świetle. Poprzez te kanaliki ( $w$ formie otwartej) mogą przenikać pomiędzy sąsiadującymi komórkami różne substancje, nawet tak duże jak cząsteczki RNA i białka. Plazmodesmy wysłane są domenami błony i ściany o specjalnym składzie chemicznym, różnym od otaczających je płaskich fragmentów [5].

Od aktywności białek Rab zależy wzrost wierzchołkowy komórek, podobnie jak ma to miejsce w komórkach zwierzęcych, na przykład neuronach tworzących dendryty. Polega on na intensywnym dobudowywaniu ściany komórkowej w jednym określonym miejscu. Mechanizm ten pozwala na tworzenie długich i wąskich wypustek. Wzrost wierzchołkowy jest charakterystyczny dla wyspecjalizowanych komórek roślinnych: włośników korzeniowych i łagiewek pyłkowych [6]. Trzeba tu zaznaczyć, że jest to mechanizm różny od wzrostu komórki spolaryzowanej, który został opisany wyżej dla komórek prostopadłościennych. W komórkach spolaryzowanych, ale nierosnących wierzchołkowo, materiał jest dobudowywany na przeciwległych ścianach komórki w sposób skoordynowany z osią polarności.

Podział cytoplazmy między komórki potomne przebiega u roślin inaczej niż u zwierząt. Sztywna ściana komórkowa otaczająca dzielącą się mitotycznie komórkę roślinną uniemożliwia utworzenie się kurczliwego pierścienia aktynowego, jak ma to miejsce $\mathrm{u}$ zwierząt. U roślin podział cytoplazmy (cytokineza) przebiega dzięki utworzeniu $\mathrm{w}$ centralnej części komórki tzw. płytki podziałowej, tworu o charakterze ściany komórkowej pierwotnej (zbudowanej z polisacharydów innych niż celuloza, np. kalozy). Płytka podziałowa powstaje z polisacharydów (cargo) i z udziałem enzymów, które muszą być dostarczane w pęcherzykach transportowych. Pojawia się pomiędzy dwoma jądrami komórkowymi powstałymi po podziale DNA. Płytka narasta od środka komórki ku istniejącym ścianom, aż do połączenia się tych dwóch struktur [7].

Organellum komórkowym pełniącym inne funkcje $\mathrm{w}$ komórkach roślinnych niż zwierzęcych jest wakuola (wodniczka). Wakuola roślin pełni funkcje trawienne (lityczne) podobnie do zwierzęcych lizosomów. W przeciwieństwie do zwierząt $u$ roślin jest także przedziałem spichrzowym, w którym magazynowane są białka i inne substancje zapa- 


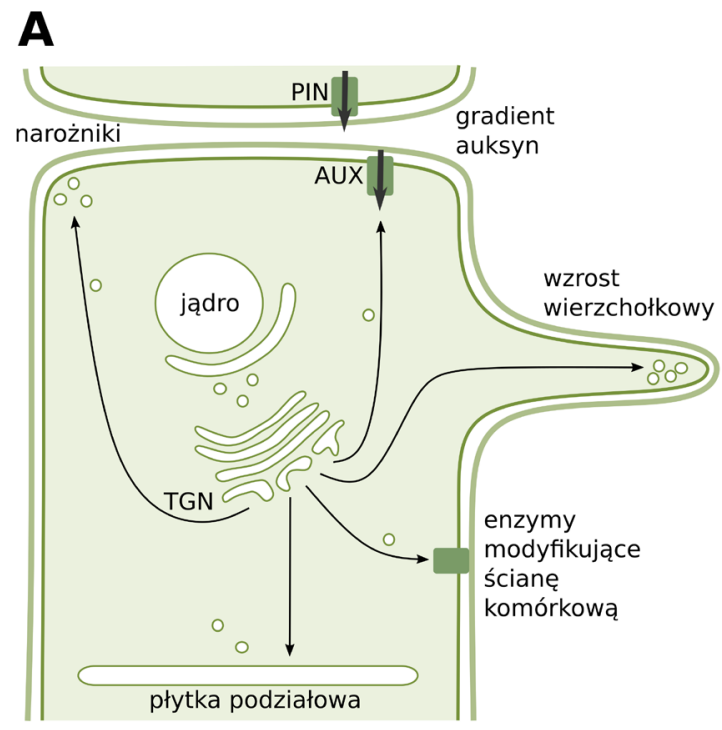

C

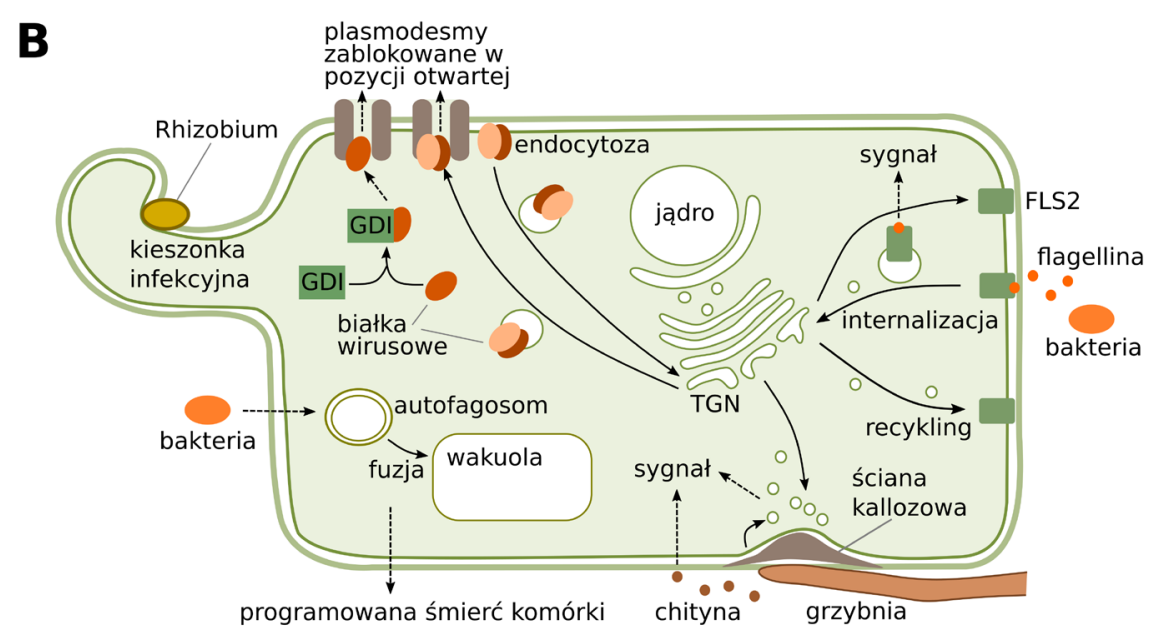

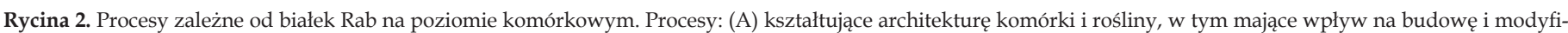

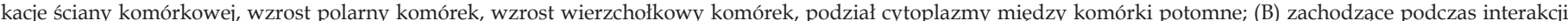

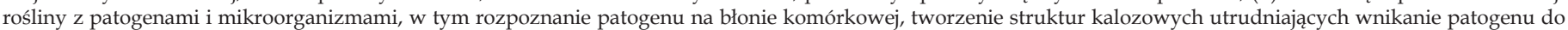

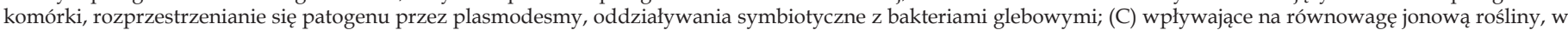
tym transport jonów sodu do wakuoli w warunkach wysokiego zasolenia, pobieranie mikroelementów.

sowe, np. skrobia. W wakuoli roślin można znaleźć związki drobnocząsteczkowe o charakterze barwników, substancji odstraszających owady, substancji smakowych, itp. Ponadto wakuola roślinna pełni ważną funkcję $\mathrm{w}$ utrzymaniu odpowiedniego ciśnienia wewnątrz komórki, w licznych tkankach wypełnia prawie całą objętość komórki. Przyrost objętości wakuoli, możliwy dzięki zwiększaniu powierzchni błony (tonoplastu) powoduje wzrost ciśnienia wewnątrz komórki. Napór wakuoli na ściany wspomaga ich rozciąganie i wzrost komórek na długość [8]. Białka Rab biorą udział w dostarczaniu do wakuoli pęcherzyków zawierających wszystkie wymienione składniki - zarówno białka, jak lipidy, a także polifenole i antocyjany.

Kolejnym przedziałem komórkowym o innej u roślin niż u zwierząt strukturze i funkcji jest system aparatu Golgiego wraz ze strukturami post-Golgi (Trans-Golgi-Network, TGN). Podczas gdy u zwierząt najczęściej występuje jeden aparat Golgiego na komórkę, w komórce roślinnej może być ich kilkadziesiąt, a nawet kilkaset. Co więcej, u zwierząt struktury TGN biorą udział w transporcie do błony komórkowej (sekrecja), podczas gdy u roślin bogata sieć tubularno-pęcherzykowych struktur TGN nie pełni funkcji tylko szlaku sekrecyjnego. TGN u roślin zaangażowany jest $\mathrm{w}$ recykling białek $\mathrm{z}$ błony komórkowej, a również odgrywa rolę późnego endosomu i struktur prewakuolarnych [9].

Białka Rab biorą udział we wszystkich procesach pączkowania i fuzji błon w systemie ER - aparat Golgiego - TGN - błona komórkowa - wakuola, oraz w transporcie, zarówno polarnym, jak i niepolarnym, do ściany komórkowej. Jest więc zrozumiałe, że nieprawidłowości w działaniu białek Rab w komórce roślinnej będą miały wpływ na wiele ważnych (biologicznie, a także biotechnologicznie) procesów, chociaż będą się przejawiały w inny sposób niż u zwierząt.

\section{BIAŁKA RAB W ORGANIZMIE ROŚLINNYM}

W roślinach naczyniowych, których modelowym przykładem jest rzodkiewnik pospolity Arabidopsis thaliana, licz- 
ba genów kodujących białka Rab wynosi blisko 60 i jest podobna jak u ssaków. Na podstawie podobieństwa sekwencji aminokwasowych roślinnych białek Rab podzielono tę rodzinę GTPaz na 8 podrodzin, oznaczanych literami od A do H [10]. Wszystkie podrodziny roślinnych białek Rab mają swoje homologi wśród białek ssaczych (Tabela 1), ale nie wszystkie podrodziny białek Rab występujące u ssaków mają homologicznych reprezentantów wśród białek roślinnych (np. Rab23, Rab35, Rab39). Największą i najbardziej zróżnicowaną podrodziną roślinnych białek Rab jest RabA (kodowana przez 23 geny w rzodkiewniku i podobną liczbę w genomach ryżu, kukurydzy czy soi). Takie zróżnicowanie w obrębie podrodzin Rab w królestwach zwierząt i roślin odzwierciedla przystosowanie do innego trybu życia i wynikające $\mathrm{z}$ tego faktu zmiany $\mathrm{w}$ budowie i funkcjonowaniu komórek oraz tkanek, które zostały opisane poniżej.

\section{WPEYW NA ARCHITEKTURĘ KOMÓREK, TKANEK I ORGANIZMÓW}

Kierowanie konkretnych białek do wyznaczonych rejonów ściany komórkowej roślin (lub przylegającej do niej błony) i związany z tym podział ściany komórkowej na różniące się od siebie domeny, to zjawiska zależne od prawidłowego funkcjonowania białek Rab (Ryc. 2A). Szczególnie ważne są w tym przypadku białka z podrodziny RabA. Najbliższym ssaczym odpowiednikiem białek RabA są Rab11, uczestniczące $\mathrm{w}$ transporcie ze struktur post-Golgi do błony komórkowej. Wydaje się, że i u roślin ta podstawowa funkcja jest zachowana. Dodatkowo u roślin białka RabA osiągnęły specjalizację w transporcie wydzielniczym do różnych domen ściany komórkowej lub struktur z niej pochodzących oraz $\mathrm{w}$ recyklingu białek i lipidów z błony komórkowej do struktur post-Golgi [11].

Białka z grupy RabA1 (kodowane w rzodkiewniku przez 9 genów) są zaangażowane przede wszystkim w transport i recykling błonowych transporterów dla najważniejszych roślinnych hormonów wzrostu - auksyn. Prawidłowa lokalizacja białek PIN (białka usuwające auksynę z komórki) i białek AUX (białka pobierające auksynę do komórki) jest polarna, tzn. są one zlokalizowane najczęściej na jednej tylko powierzchni prostopadłościennej komórki. Dzięki temu ścieżka przepływu auksyn przez tkankę jest ściśle ukierunkowana. Od kierunku przepływu auksyn zależy wyznaczenie osi góra-dół w łodydze i korzeniu rośliny oraz plastyczność wzrostu w odpowiedzi na zmianę ułożenia rośliny względem przyciągania ziemskiego i światła słonecznego. Dla organizmów osiadłych, jakimi są przecież rośliny, dopasowanie się do środowiska jest sprawą kluczową.

W rzodkiewniku białka RabA1 i RabA2 kierują pęcherzyki do właściwego fragmentu błony. Niektóre są wyspecjalizowane $\mathrm{w}$ transporcie do górnej lub dolnej powierzchni prostopadłościennej komórki, inne w recyklingu pęcherzyków zawierających transportery auksyn z przeciwległej powierzchni (proces transcytozy). Z tego względu nieprawidłowości w działaniu białek RabA uniemożliwiają ustanowienie osi polarności komórki $[12,13]$. Również białka RabE są zaangażowane w ten proces. Mutanty Arabidopsis $\mathrm{w}$ genie kodującym białko SCD (ang. stomatal çytokinesis defective), kodującym czynnik wymiany nukleotydu (GEF) dla
RabE, gromadzą transporter auksyny PIN2 w pęcherzykach wewnątrz komórki. Nieprawidłowa lokalizacja PIN2 utrudnia właściwy przepływ auksyny do korzenia i prowadzi do wzrostu w kierunku niezależnym od przyciągania ziemskiego [14]. Zaburzenia grawitropizmu pędu występują $\mathrm{w}$ rzodkiewniku również $\mathrm{u}$ mutanta $\mathrm{z}$ wyciszonym genem Rgtb1, kodującym jedną z podjednostek kompleksu enzymatycznego wprowadzającego kotwice lipidowe do białek $\mathrm{Rab}$ [15].

Z kolei białko RabA5c w Arabidopsis jest niezbędne do zachowania prawidłowych kształtów komórek, a konkretnie do utworzenia krawędzi w komórkach prostopadłościennych. Odpowiada ono za transport pęcherzyków do krawędzi pomiędzy dwiema ścianami (którą możemy postrzegać jako wyspecjalizowaną domenę ściany). Brak tego białka powoduje odkształcenia komórek. Można przypuszczać, że pęcherzyki zawierające RabA5c przenoszą enzym usztywniający ścianę komórkową na krawędziach komórek [16].

Białka z grupy RabA4 są wyspecjalizowane w transporcie materiału do stref wzrostu wierzchołkowego w łagiewkach pyłkowych (RabA4d) i włośnikach korzeniowych (RabA4b) rzodkiewnika [17]. W przypadku łagiewek pyłkowych pokazano to również w tytoniu [18]. Białka z grupy RabA4 wiążą się specyficznie $\mathrm{z}$ fosfatydyloseryną, a także z enzymami wzbogacającymi błonę komórkową w fosforany inozytolu. Wydaje się, że w ten sposób rozpoznają i dalej modyfikują domeny błony komórkowej o dużej płynności i podatności na odkształcenia - czyli między innymi właśnie wierzchołki wzrostu polarnego $[19,20]$. Także mutacje w genach kodujących białka Rab z innych podrodzin przejawiają się nieprawidłowościami we wzroście wierzchołkowym. Na przykład białka RabE w Arabidopsis modyfikuja skład lipidów w otaczającej je błonie, co prowadzi do rozgałęziania się włośników korzeniowych [21,22]. U mchu Physcomitrella patens białko RabE oddziałuje z miozyną IX i bierze udział we wzroście wierzchołkowym komórek gametofitu [23]. Mutacje w genie kodującym białko LOT (ang. loss of TGN), które jest czynnikiem wymiany nukleotydu dla białek z podrodziny $\mathrm{RabH}$, spowalniają u A. thaliana wzrost łagiewek pyłkowych i zaburzają ich zdolność odnajdywania zalążni w słupkach [24]. Co więcej w mutancie lot skład fosfolipidów budujących łagiewkę oraz wydzielanie pektyn na jej wierzchołku są inne niż w roślinach typu dzikiego. Do zaburzeń lub zahamowania wzrostu łagiewek pyłkowych rzodkiewnika prowadzą również mutacje $\mathrm{w}$ genach kodujących białka z podrodziny RabD [25].

W transporcie pęcherzyków do płytki podziałowej $\mathrm{W}$ Arabidopsis biorą udział białka z podrodziny RabA (RabA1c, RabA1e, a także RabA2a i RabA3). Pęcherzyki wyznakowane białkami RabA z tych klas mają wspólny przedział docelowy (płytka podziałowa). Prawdopodobnie jednak mają różną zawartość (transportują różne enzymy/składniki ściany), gdyż nie kolokalizują ze sobą wzajemnie [26-30].

W dostarczaniu konkretnych czynników w różne rejony ściany komórkowej lub przylegającej do niej błony uczestniczą białka z różnych podrodzin Rab. Na przykład mutanty Arabidopsis z wyciszonymi genami kodującymi białka RabA $\mathrm{z}$ różnych podklas miały zmienioną zawartość poszczegól- 


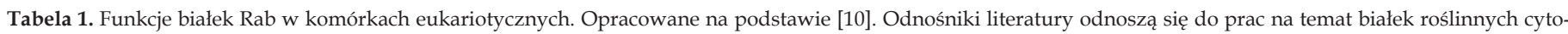
wanych w niniejszym opracowaniu.

\begin{tabular}{|c|c|c|c|c|}
\hline Proces & Drożdże & Ssaki & Rośliny & Literatura \\
\hline transport ER-Golgi & Ypt1p & Rab1 & $\begin{array}{l}\text { RabD1, } \\
\text { RabD2a, RabD2b, RabD2c }\end{array}$ & $25,41,73,87$ \\
\hline $\begin{array}{l}\text { transport w aparacie Golgiego, } \\
\text { transport wsteczny Golgi-ER }\end{array}$ & Ypt6p & Rab6 & $\begin{array}{l}\text { RabH1a, RabH1b, RabH1c, } \\
\text { RabH1d, RabH1e }\end{array}$ & $24,32,61$ \\
\hline Golgi & - & Rab19, Rab30, Rab33 & - & \\
\hline $\begin{array}{l}\text { transport Golgi-błona komórkowa, } \\
\text { sekrecja }\end{array}$ & Sec $4 p$ & Rab8 & $\begin{array}{l}\text { RabE1a, RabE1c, } \\
\text { RabE1d, RabE1e }\end{array}$ & $\begin{array}{l}14,21,23 \\
52,53,82\end{array}$ \\
\hline wyspecjalizowane ścieżki sekrecyjne & - & $\begin{array}{l}\text { Rab35, Rab13, Rab10, } \\
\text { Rab26, Rab37, } \\
\text { Rab12, Rab3, Rab27, } \\
\text { Rab35,Rab40 }\end{array}$ & - & \\
\hline transport polarny, transcytoza & Ypt10p & $\begin{array}{l}\text { Rab17, Rab21, } \\
\text { Rab22, Rab24 }\end{array}$ & 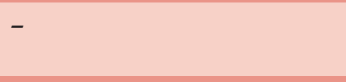 & \\
\hline $\begin{array}{l}\text { transport post-Golgi-błona komórkowa, } \\
\text { recykling błona komórkowa-endosom; } \\
\text { transport polarny, transcytoza }\end{array}$ & Ypt31/Ypt32p & $\begin{array}{l}\text { Rab11, } \\
\text { Rab25 }\end{array}$ & $\begin{array}{l}\text { RabA1a, RabA1b, RabA1c, } \\
\text { RabA1d, RabA1e, RabA1f, } \\
\text { RabA1g, RabA1h, RabA1i, } \\
\text { RabA2a, RabA2b, } \\
\text { RabA2c, RabA2d, } \\
\text { RabA3, } \\
\text { RabA4a, RabA4b, RabA4c, } \\
\text { RabA4d, RabA4e, } \\
\text { RabA5a, RabA5b, RabA5c, } \\
\text { RabA5d, RabA5e, } \\
\text { RabA6a, RabA6b }\end{array}$ & $\begin{array}{l}11,12,13,16,17, \\
18,19,20,26,27, \\
28,29,30,31,34, \\
36,37,38,46,47, \\
54,62,63,64,79\end{array}$ \\
\hline endocytoza & Ypt51/52/53p & Rab5 & $\begin{array}{l}\text { RabF1, } \\
\text { RabF2a, RabF2b }\end{array}$ & $\begin{array}{l}34,35,39,40,48, \\
49,51,57,58, \\
60,67,68,69, \\
70,71,72,74, \\
83,84,85,86\end{array}$ \\
\hline wyspecjalizowane endosomy & - & $\begin{array}{l}\text { Rab9, Rab32, Rab38, } \\
\text { Rab29 Rab23, Rab20, } \\
\text { Rab28, Rab34, Rab36 }\end{array}$ & - & \\
\hline $\begin{array}{l}\text { recykling błona komórkowa- } \\
\text { endosom- błona komórkowa }\end{array}$ & - & Rab4, Rab14, Rab39 & - & \\
\hline $\begin{array}{l}\text { transport endosom-wakuola, } \\
\text { endosom-lizosom, } \\
\text { fuzja wakuoli; autofagia }\end{array}$ & Ypt7p & Rab7 & $\begin{array}{l}\text { RabG1, } \\
\text { RabG2, } \\
\text { RabG3a, RabG3b, } \\
\text { RabG3c,RabG3d, } \\
\text { RabG3e, RabG3f }\end{array}$ & $\begin{array}{l}42,55,59 \\
88,89,90\end{array}$ \\
\hline $\begin{array}{l}\text { transport wsteczny } \\
\text { endosomy- ER, autofagia, } \\
\text { ER- krople lipidowe }\end{array}$ & - & Rab18 & $\begin{array}{l}\text { RabC1, } \\
\text { RabC2a, RabC2b }\end{array}$ & $43,56,65,66$ \\
\hline $\begin{array}{l}\text { transport wsteczny przedziały } \\
\text { prewakuolarne-Golgi- ER }\end{array}$ & - & Rab2 & RabB1a, RabB1b, RabB1c & 65 \\
\hline
\end{tabular}

nych składników ściany komórkowej. Mutanty w genach kodujących białka RabA1 miały obniżoną zawartość pektyn, a RabA4 hemicelulozy [31]. Ważną funkcję wykazano dla białka RabH1b. Uczestniczy ono w składaniu i posttranslacyjnej modyfikacji kompleksów syntazy celulozy (CESA) w aparacie Golgiego lub w strukturach post-Golgi [32]. Wyciszenie genu kodującego RabH1b w rzodkiewniku prowadzi do nagromadzenia pęcherzyków wokół nieprawidłowo zbudowanego aparatu Golgiego („spuchnięte” cysterny). Kompleksy syntazy celulozy są $\mathrm{w}$ tym mutancie nieregularnie rozmieszczone $\mathrm{w}$ błonie komórkowej, co prowadzi do obniżenia całkowitej zawartości celulozy w ścianie komórkowej i zamierania siewek.

Zatem wydaje się, że główną grupą białek Rab regulującą transport do wyspecjalizowanych domen ściany komórkowej są w roślinach RabA (mogą one przenosić enzymy syn- tetyzujące lub modyfikujące składniki ściany), ale w procesach tych biorą udział również białka Rab z innych podrodzin. Mutacje w genach kodujących białka Rab z wczesnej i późnej ścieżki sekrecyjnej: ER-aparat Golgiego-struktury post Golgi-błona komórkowa mają bezpośredni lub pośredni wpływ na architekturę ścian komórkowych. Zwielokrotnienie liczby genów kodujących białka z podrodziny RabA oraz ich dalsza specjalizacja u roślin rekompensują brak innych podrodzin białek Rab zaangażowanych w sekrecję $\mathrm{u}$ zwierząt (przykłady w Tabeli 1).

\section{ODPORNOŚĆ ROŚLIN NA PATOGENY I INTERAKCJE Z MIKROORGANIZMAMI}

Podobnie jak u zwierząt, tak i u roślin białka Rab odgrywają istotną rolę $\mathrm{w}$ obronie organizmu przed patogenami [33], (Ryc. 2B). Białka Rab zaangażowane są w pierwszą li- 
nię obrony, na etapie wnikania komórek patogenu do tkanek rośliny.

Roślinny receptor błonowy FLS2 rozpoznaje flagelinę, białko budujące wici bakteryjne. Dzięki temu wykrywa obecność patogennych bakterii w środowisku komórki. W rzodkiewniku białko RabA1b bierze udział w transporcie FLS2 do błony komórkowej, a RabA6a i RabA4c w recyklingu tego receptora. Po związaniu przez receptor FLS2 peptydu pochodzącego $\mathrm{z}$ flageliny, taki załadowany receptor FLS2 pobierany jest do cytoplazmy za pomocą pęcherzyków zawierających RabF2b. Tam następuje aktywacja kaskady sygnałowej, która prowadzi do obrony rośliny przed inwazją patogenu [34]. Jedną z reakcji po wykryciu flageliny przez FLS2 jest zamknięcie aparatów szparkowych liści.

Przez pory aparatów szparkowych patogeny z łatwością wnikają do przestrzeni apoplastycznej roślin. Światło tych otworów jest kontrolowane w sposób zależny od wilgotności powietrza, stężenia $\mathrm{CO}_{2}$ i obecności patogenów. Aparaty szparkowe są zamykane zarówno po wykryciu przez roślinę flageliny, jak i chityny (buduje ścianę komórkową grzybów). Zamknięcie aparatów szparkowych ma nie dopuścić do wrastania strzępek grzybni do wnętrza liścia. Mutanty Arabidopsis w genach kodujących RabF1, RabF2a i RabF2b nie reagują prawidłowo na podanie flageliny i chityny (nie zamykają aparatów szparkowych), chociaż osłabienie reakcji odpornościowej przebiega u każdego z nich w inny sposób. Sugeruje to, że każdy z mutantów pełni inną, niezależną funkcję w szybkiej reakcji na patogen [35].

Białka Rab w roślinach stanowią bezpośredni cel ataku grzybów z rodzaju Phytophtora. Grzyby te wywołują zgniliznę ziemniaka i pomidora. Choroba ta łatwo rozprzestrzenia się w uprawach i powoduje wielkie straty w rolnictwie. Stwierdzono tworzenie kompleksów między czynnikiem wirulencji Phytophtora RxLR a białkami z rodziny RabA1. Utworzenie takiego kompleksu „wymiareczkowuje” białka Rab w komórce i blokuje transport białek systemu odpornościowego rośliny, np. białka PR-1 (ang. Pathogenesis Related) do przestrzeni apoplastycznej. Taki efekt uzyskano $\mathrm{w}$ ziemniaku i rzodkiewniku [36]. Na dalszych etapach obrony rośliny, gdy patogen wniknie już do tkanek rośliny, w Arabidopsis aktywne jest na przykład białko RabA4c. Znakuje ono peccherzyki niosące materiał do budowy „zatyczek kalozowych", struktur izolujących miejsca inwazji strzępek grzyba do komórki roślinnej. RabA4c bezpośrednio oddziałuje z syntazą kalozy i aktywuje jej funkcje enzymatyczne [37]. Można więc powiedzieć, że odgrywa rolę w niespecyficznej odpowiedzi odpornościowej rośliny.

Z tej samej podrodziny RabA4 pochodzi białko RabA4b, które ma z kolei wpływ na niespecyficzną odpowiedź odpornościową rzodkiewnika na bakterie Pseudomonas syringae. Oddziałuje ono bezpośrednio z ligazą ubikwityny pUB13 i kompleks ten aktywuje kaskadę przekazywania sygnału zależną od kwasu salicylowego. Jest to główna ścieżka sygnalizacyjna w odpowiedzi na stres biotyczny. Jednym z efektów aktywacji tej ścieżki sygnałowej jest odkładanie się niespecyficznych agregatów kalozowych w zaatakowanych przez bakterię Pseudomonas liściach. Późniejszym efek- tem jest wzrost ekspresji genów kodujących białka zaangażowane w walkę z patogenem [38].

Wszystkie białka RabF w roślinach mają wspólny czynnik wymiany nukleotydu, czyli GEF - VPS9. Mutacje w genie kodującym białko VPS9a osłabiają reakcje odporności roślin na niektóre grzyby, na przykład powodujące mączniaka prawdziwego (Golovinomyces orontii, Blumeria graminis, Hyaloperonospora arabidopsii). W odpowiedzi na wniknięcie strzępek grzybów w zaatakowanych komórkach rośliny tworzą się struktury utworzone ze ścian komórkowych wzbogaconych w kalozę. Otaczają one ściśle strzępki i mechanicznie odgradzają miejsce infekcji od zdrowej tkanki. Struktury kalozowe utrudniają rozrastanie się grzybni oraz pobieranie substancji odżywczych z komórek gospodarza. W roślinach Arabidopsis z mutacją w genie Vps9a białka RabF są uwięzione w formie nieaktywnej i nie transportują materiału potrzebnego do utworzenia struktur kalozowych. Rozwój infekcji jest więc znacząco przyspieszony [39]. Jednocześnie wykazano, że na błonie otaczającej strzępkę grzyba występują roślinne białka RabF1, F2a i F2b, ale nie występują na niej białka z grupy RabG. Błona ta ma więc raczej charakter endosomu, a nie wakuoli. Białka RabF są obecne na jej powierzchni aż do momentu utworzenia ściany kalozowej, a potem zanikają [40]. W jęczmieniu pokazano, że również białka RabD są obecne w strukturach błonowych otaczających miejsca ataku Blumeria graminis (jednego z patogenów wywołujących mączniaka prawdziwego). Rośliny z wyciszonym genem kodującym białko RabD miały niższą odporność na ten patogen [41].

Gdy patogen wniknie już do rośliny, białka Rab biorą udział w dalszych procesach obronnych. Na przykład podczas zakażenia Arabidopsis patogennym szczepem bakterii Pseudomonas syringae jednym $\mathrm{z}$ pierwszych widocznych objawów na liściach jest chloroza i zamieranie komórek. Celem tych procesów jest odgraniczenie tkanek zaatakowanych od zdrowych i uniemożliwienie patogenowi rozprzestrzeniania się. Pokazano, że procesy te mają charakter programowanej śmierci komórki i bierze w nich udział białko RabG3b. Białka RabG występują na późnych endosomach i odpowiadają za ich fuzję z wakuolą, a także biorą udział w procesach autofagocytozy i programowanej śmierci komórki. RabG3b ułatwia fuzję autofagosomów i lizę zaatakowanych bakteriami komórek [42]. Z kolei atak patogenu grzybowego wywołującego rdzę żółtą (Puccinia striiformis) na pszenicę aktywuje transkrypcję genu kodującego białko RabC. Wyciszenie tego genu obniża odporność roślin na ten patogen. Prawdopodobnie i w tym przypadku RabC odpowiada za obumieranie zainfekowanych komórek, co uniemożliwia dalsze rozprzestrzenianie się infekcji na liściach [43].

Duże straty w uprawach roślin kapustowatych powoduje grzyb Verticillium. Wykazano, że w Arabidopsis po infekcji tym grzybem białko RabGAP22 (czynnik aktywujący hydrolizę GTP w białkach Rab) tworzy kompleks z enzymem AGT1 (ang. serine glyoxylate aminotransferase) w peroksysomach. Powstanie tego kompleksu aktywuje kaskadę sygnałową kwasu abscysynowego (hormonu stresu u roślin). RabGAP22 bierze też udział w innych ścieżkach przekazywania sygnału stresowego: reakcji na hormon brasinosteroidowy, 
a także w zamykaniu aparatów szparkowych w odpowiedzi na obecność patogenów w środowisku [44]. Innym białkiem nadrzędnym w stosunku do wielu białek Rab jest GDI, inhibitor dysocjacji GDP, który umożliwia recykling białek Rab z błony docelowej do cytoplazmy. Strzępki patogennego grzyba silnie aktywują ekspresję genów kodujących obie formy GDI w roślinach ryżu. Dzięki temu rośliny mogą szybciej i skuteczniej przygotować system transportu pęcherzykowego do odpowiedzi na atak patogenu [45].

Interakcja rośliny z mikroorganizmem może mieć charakter symbiotyczny, czego przykładem jest powstawanie brodawek korzeniowych. We wczesnych stadiach tworzenia się brodawek korzeniowych u roślin motylkowych udział biorą białka z podrodziny RabA. U fasoli z wyciszonym genem kodującym białko RabA2 włośniki korzeniowe nie tworzą kieszonek infekcyjnych, które mogłyby być skolonizowane przez symbiotyczne bakterie Rhizobium [46]. Nawet jeśli dojdzie do zasiedlenia kieszonki przez komórki bakterii, to wzrost nici infekcyjnej przerastającej przez włośnik korzeniowy jest zahamowany lub dochodzi do jej rozerwania [47].

Wirusy, które wykorzystują maszynerię komórkową gospodarza, by się replikować i rozprzestrzeniać, potrafią wykorzystywać procesy zależne od białek Rab, tak u zwierząt, jak i u roślin. Przykładem jest wirus mop-top ziemniaka, powodujący znaczne uszkodzenia bulw. Rozprzestrzenia się on w roślinie poprzez kanaliki plazmodesm. Białka kodowane w genomie wirusa wykorzystują endosomy zawierające RabF2b, by dostać się do plazmodesm i zablokować ich zamykanie [48]. Wirus mozaiki bambusa wykorzystuje pęcherzyki zawierające RabF1 do rozprzestrzeniania się $\mathrm{W}$ roślinie będącej gospodarzem. Białko RabF1 pozbawione palmitoilowej reszty kotwiczącej do błony lub zablokowane w formie nieaktywnej (związanej z GDP) uniemożliwia rozprzestrzenianie się infekcji na komórki sąsiadujące [49].

Inny wirus, RBSDV (ang. rice black-streaked dwarf virus), atakuje rośliny uprawne jednoliścienne, takie jak kukurydza czy ryż, powodując duże straty w uprawach. Wirus ten wytwarza białko, które stabilizuje otwory plazmodesm, by umożliwić rozprzestrzenianie się patogenu w roślinie. Jednocześnie białko to wiąże się specyficznie z GDI (czynnikiem przenoszącym zdezaktywowane białka Rab z błon docelowych do cytoplazmy). Prawdopodobnie umożliwia to wirusowi łatwiejszy dostęp do pęcherzyków zawierających białka Rab i transport „na gapę” do plazmodesm. Niektóre rośliny kukurydzy niosą skrócony allel genu kodującego białko GDI. Powstające skrócone roślinne białko GDI nie tworzy kompleksu z białkiem wirusowym. Dzięki temu rośliny kukurydzy niosące ten allel są odporne na pierwotną infekcję wirusem RBSDV [50].

TBSV (ang. tomato bushy stunt virus), wirus karłowatości pomidora, podobnie jak wiele innych wirusów roślinnych, tworzy w komórkach gospodarza specjalne struktury, złożone z wielu "przechwyconych” cząsteczek białek i lipidów. W takich otoczonych błoną strukturach łatwiej jest wirusowi "ukryć się" przed mechanizmami obronnymi gospodarza i prowadzić wydajną replikację. Komórki gospodarza rozpoznają błonę zewnętrzną tych struktur jako własną i nieszkodliwą. Białka replikacji wirusa oddziałują bezpośrednio z białkami RabF, co prowadzi do powstania struktur wewnątrzkomórkowego „kamuflażu” wirusa [51].

Białka z podrodziny RabE w formie konstytutywnie aktywnej (związanej z GTP) spowalniają rozprzestrzenianie się $\mathrm{W}$ roślinie infekcji wirusem mozaiki rzepy TuMV [52]. RabE, które są odpowiednikami ssaczych Rab8 i drożdżowych Sec4p, transportują pęcherzyki bezpośrednio $z$ aparatu Golgiego do ściany komórkowej i znakują maleńkie pęcherzyki grupujące się pod powierzchnią błony komórkowej. RabE z rzodkiewnika oddziałują bezpośrednio z czynnikiem wirulencji patogenu AvrPto z bakterii Pseudomonas syringae [53].

\section{ZASOLENIE I RÓWNOWAGA JONOWA}

Zaburzenia w funkcjonowaniu białek Rab mogą wpływać na zdolność rośliny do regulacji równowagi jonowej oraz na jej odporność na zmiany stężeń jonów w otoczeniu (Ryc. 2C). Rośliny Arabidopsis niosące mutacje jednocześnie w kilku genach kodujących białka RabA1 są wrażliwsze na zasolenie, choć wykluczono, że białka te uczestniczą bezpośrednio w transporcie i recyklingu kanałów jonowych [54]. Z kolei ekspresja genów kodujących białka RabC i RabG bardzo silnie wzrasta, gdy rośliny ryżu hodowane są w zasolonej glebie lub przy niedostatku wody, a także pod wpływem hormonu spoczynku - kwasu abscysynowego $[55,56]$. Także RabF1 pośredniczy w reakcjach roślin na zasolenie (zarówno w rzodkiewniku, jak i w mango oraz halofitach), jednak mechanizm tego zjawiska nie jest w pełni poznany. Wiadomo, że zmniejszenie wydajności wymiany nukleotydu w białkach RabF przez zablokowanie funkcji VPS9 (białka GEF dla podrodziny RabF) zwiększa wrażliwość roślin rzodkiewnika na zasolenie. Rośliny rzodkiewnika typu dzikiego narażone na stres solny aktywują dodatkową ścieżkę endocytozy, niezależną od klatryny i niespecyficzną wobec pobieranego "cargo". Ponadto wakuole w wewnętrznych warstwach komórek korzenia powiększają znacząco swoją objętość. Żadna z tych niespecyficznych linii obrony przed zasoleniem nie jest wykorzystywana w mutantach ops9 [57]. Wrażliwość mutantów ops9 na zasolenie wiąże się z rozregulowaniem równowagi sodowo-potasowej w komórkach korzenia, obniżeniem stężenia wewnątrzkomórkowego jonów potasu i alkalizacją wakuoli [58]. Innym przykładem jest rola odpowiednika białka RabG w ryżu (OsRab7). Nadprodukcja tego białka poprawia odporność na suszę i zasolenie gleby. Nawet w warunkach stresowych rośliny takie są zdolne do wydania dość wysokich plonów. Proponowany mechanizm odporności na suszę wiąże się także w tym przypadku z homeostazą jonową w wakuoli [59].

Dobrze poznanym przykładem roli białek Rab w regulacji równowagi jonowej jest udział RabF2 w regulacji pobierania boru - mikroelementu niezbędnego do wzrostu roślin. Związki boru z oligocukrami wzmacniają mechanicznie ścianę komórkową, a jego niedobór w środowisku prowadzi do karłowacenia roślin. Jednocześnie nadmiar tego mikroelementu w glebie jest dla roślin silnie toksyczny. Regulacja pobierania jonów boru ze środowiska jest więc kluczowa dla optymalnego wzrostu roślin. W rzodkiewniku dwa białka RabF2, zlokalizowane na wczesnych i późnych 
endosomach, pośredniczą $\mathrm{w}$ transporcie do wakuoli oraz $\mathrm{w}$ endocytozie i recyklingu białek receptorowych $\mathrm{z}$ błony komórkowej. Jednym z transportowanych tą drogą białek jest białko BOR1, transporter boru. W warunkach wysokiego stężenia boru w otoczeniu białko BOR1 jest pobierane w pęcherzykach zawierających RabF2a do cytoplazmy, a następnie przekazywane do wakuoli do degradacji. Endocytoza BOR1 jest więc jednym z mechanizmów utrzymywania właściwego stężenia jonów boru wewnątrz rośliny [60].

Żelazo jest ważnym mikroelementem i kofaktorem wielu kluczowych enzymów, w tym zaangażowanych w fotosyntezę. Nadekspresja genu kodującego odpowiednik białka RabH w ryżu (OsRab6) prowadzi do zwiększenia produkcji nasion w warunkach deficytu żelaza w podłożu. Ekspresja genu kodującego to białko jest silnie regulowana przez dostępność jonów $\mathrm{Fe}^{3+}$ w środowisku. W warunkach niedoboru tego pierwiastka rośliny ryżu ze zwiększoną zawartością Rab6a sprawniej rekompensują jego pobieranie przez wytworzenie bardziej rozbudowanego systemu korzeniowego [61].

\section{PRODUKCJA ROLNICZA - DOJRZEWANIE OWOCÓW, ZAWARTOŚĆ SUBSTANCJI SPICHRZOWYCH}

Rodzina białek RabA jest duża i zróżnicowana u wszystkich gatunków roślin, w tym użytkowych. Analiza wpływu mutacji w kodujących je genach oraz analizy proteomiczne i transkryptomiczne potwierdzają opisaną tezę o transporcie enzymów modyfikujących ścianę komórkową przez pęcherzyki zawierające białka RabA. Białka RabA mają w związku z tym istotny wpływ na jakość produktów rolniczych (Ryc. 3A). Na przykład w owocach pomidora wyciszenie genu dla białka homologicznego do RabA1a z Arabidopsis spowodowało opóźnienie mięknięcia miąższu i przedłużenie trwałości owocu. Jednocześnie stwierdzono niższą aktywność enzymów trawiących polisacharydy: pektynoesterazy i poligalakturonazy oraz obniżoną zawartość pektyn na początku fazy dojrzewania owocu [62,63]. W owocach innych gatunków roślin uprawnych (brzoskwinia, mango, winogrona) również obserwowano wzrost ekspresji genów kodujących białka RabA skorelowany ze wzrostem aktywności enzymów „rozluźniających” strukturę ściany komórkowej (podsumowane w [64]). W trakcie dojrzewania owoców miękkich w tkankach miękiszowych silnie rośnie transkrypcja genów kodujących białka RabB i RabC [65]. Ekspresja genów kodujących RabC jest indukowana również w strefie odcinania szypułki od łodygi w owocach oliwki [66].

Białka Rab wpływają na jakość produkcji rolnej również przez modyfikowanie zawartości substancji spichrzowych w roślinach. W ryżu mutacje w genie kodującym homolog białka VPS9 (czynnik wymiany nukleotydu dla RabF) zaburzają transport białek spichrzowych do wakuoli w bielmie ziarniaka. Zmiany te korelują z obniżeniem zawartości głównych enzymów syntetyzujących i rozkładających skrobię [67]. Zahamowanie cyklu GTP-azowego białek RabF prowadzi do uwalniania transportowanych w pęcherzykach białek spichrzowych do cytoplazmy. Ich niedobór w wyspecjalizowanych wakuolach w bielmie ziarniaków ryżu skutkuje obniżeniem jakości spożywczej ziaren i mąki z nich uzyskanej [68]. Podobnie mutacje w genie kodującym RabF2a dezaktywujące wiązanie GTP w białku uniemożliwiają
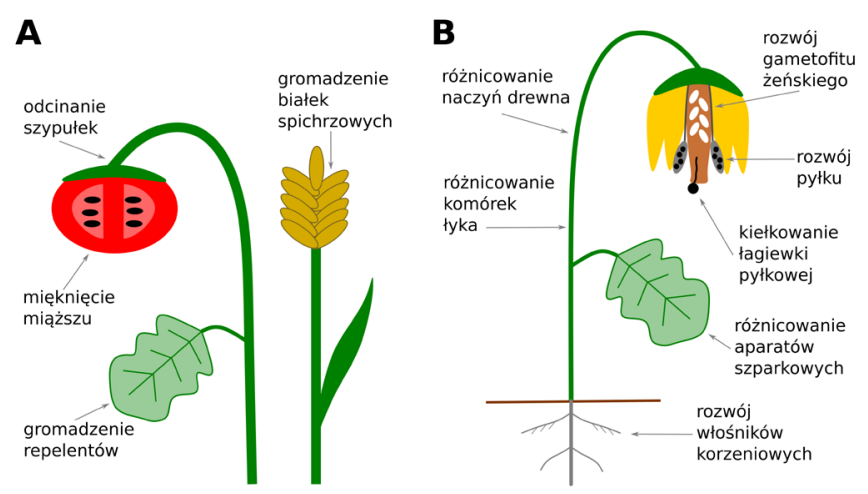

Rycina 3. Procesy zależne od białek Rab na poziomie organizmu. Procesy: (A) mające bezpośrednie znaczenie dla produkcji rolniczej, takie jak dojrzewanie owoców, gromadzenie substancji spichrzowych w ziarniakach zbóż, odcinanie szypułek owoców i gromadzenie substancji odstraszających roślinożerców; (B) wpływające na różnicowanie i rozwój rośliny, w tym różnicowanie wyspecjalizowanych typów komórek zależne od stężenia auksyn, dojrzewanie elementów tkanek zależne od programowanej śmierci komórek.

transport nowo syntetyzowanych białek spichrzowych do wakuoli w ryżu, rzodkiewniku i tytoniu [69-71]. Obniżoną zawartość skrobi, a podwyższoną cukrów prostych obserwowano też w mutancie $A$. thaliana $\mathrm{z}$ wyciszonym genem kodującym białko RabF1 [72]. U pszenicy mutacje w genie kodującym białko RabD2a prowadziły do znacznego obniżenia zawartości białek spichrzowych w bielmie nasion. Niekorzystnie wpływało to na jakość mąki i konsystencję ciasta z niej uzyskanego [73].

Jeszcze innym przykładem wpływu białek Rab na istotne dla rolnictwa właściwości roślin może być udział RabF1 w transporcie do wakuoli myrozynazy, enzymu produkującego toksyczne substancje, które odstraszają owady żerujące na roślinach kapustowatych [74].

\section{ROLA BIAŁEK RAB W ROZWOJU I RÓŻNICOWANIU KOMÓREK I TKANEK}

Białka Rab mają istotny wpływ na rozwój rośliny ze względu na ich rolę w regulacji przepływu auksyny, wspomnianą już w kontekście polarności komórki (Ryc. 3B). Stężenie auksyn, modulowane przez obecność białek PIN i AUX (odpowiednio eksportujących i importujących auksynę do komórek) na odpowiednich powierzchniach błon komórkowych, wpływa na polarność komórek i - co za tym idzie - całych organów. Przykładem może być ukierunkowany w dół wzrost korzeni. Gradient stężenia auksyn decyduje również o różnicowaniu się komórek wyspecjalizowanych, takich jak komórki przyszparkowe aparatów szparkowych liści, komórki gametofitu żeńskiego czy komórki mające utworzyć elementy wiązek łyka [75-77]. Nieprawidłowa lokalizacja białek PIN lub ich internalizacja z błony komórkowej do pęcherzyków wewnątrzkomórkowych prowadzi do zatrzymania lub przynajmniej opóźnienia procesów różnicowania komórek. Nieprawidłową lokalizację białek PIN możemy zaobserwować w Arabidopsis w mutantach, w których zaburzona jest aktywność wszystkich białek Rab, na przykład $\mathrm{w}$ roślinach $\mathrm{z}$ mutacjami w genie kodującym białko RGTB1, niezbędne dla przyłączenia reszty geranylogeranylowej do białek Rab [78]. Podobne efekty widoczne są też w mutancie dezaktywującym w rzodkiewniku całą 
podrodzinę Rab, na przykład $\mathrm{w}$ roślinach $\mathrm{z}$ mutacjami $\mathrm{w}$ genie VAN4, kodującym podjednostkę czynnika GEF dla białek z rodziny RabA [79]. I tak, u Arabidopsis mutacje w genie kodującym podjednostkę beta RGT zaburzają rozwój zarówno pyłku, jak i gametofitu żeńskiego [80, 78], zaś u mchu Physcomitrella patens mutacje w genach kodujących podjednostki kompleksu enzymatycznego RGT są letalne, gdyż w ich wyniku nie powstają gamety [81].

Białka Rab oddziałują na procesy rozwojowe u roślin także dlatego, że zaburzają tworzenie się płytki podziałowej i cytokinezę. Mutacje w genie $S C D$, który koduje czynnik wymiany nukleotydu (GEF) dla RabE1, przejawiają się nieprawidłową cytokinezą i nagromadzeniem pęcherzyków wydzielniczych w pobliżu powstającej płytki podziałowej. Na poziomie organizmu przejawia się to utworzeniem nieprawidłowych aparatów szparkowych w liściach i pędach, rozgałęzionych włośników korzeniowych i brakiem trichomów (struktur wydzielniczych) na liściach [14]. Zarówno $\mathrm{w}$ roślinach rzodkiewnika, jak i pomidora wyciszenie genu dla białka RabE1 powoduje deformacje liści, a w roślinach tytoniu także nieprawidłowości w rozwoju korzeni [82]. Zahamowanie aktywności GTP-azowej RabE1 prowadzi też do braku cytokinezy w aparatach szparkowych liści, a w konsekwencji do problemów z wymianą tlen / dwutlenek węgla.

U roślin występują dwie grupy białek RabF: F1 i F2. Białka RabF2 podlegają podwójnej geranylogeranylacji (podobnie jak większość białek Rab) i odgrywają rolę w transporcie endosom-wakuola analogiczną do podrodziny zwierzęcych Rab5. Natomiast białka RabF1, choć na poziomie sekwencji wykazują duże podobieństwo do RabF2, różnią się od pozostałych białek Rab typem modyfikacji lipidowej, gdyż są palmitoilowane. Już sam fakt innej modyfikacji lipidowej może wpływać na ich funkcję i lokalizację, gdyż reszty palmitoilowe mają powinowactwo do domen błonowych o uporządkowanej, pseudokrystalicznej strukturze, podczas gdy reszty geranylogeranylowe do rejonów bardziej płynnych i nieuporządkowanych. Ponadto, podrodzina RabF jest zaangażowana w procesy endocytozy i również przez regulację tego procesu może lokalnie wpływać na skład błon. Białka RabF1 lokalizują w pęcherzykach transportujących sterole i być może biorą udział w regulacji polarnego rozmieszczenia tych lipidów w błonie komórkowej roślin [83]. U rzodkiewnika mutacje w genie VPS9 (kodującym czynnik GEF dla RabF), które dezaktywują wszystkie białka RabF, są letalne w rozwoju zarodkowym na etapie torpedo [84]. Mutacje wyciszające, ale nie dezaktywujące ekspresję genu kodującego VPS9a, zaburzają rozwój merystemu korzenia i epidermy liści. Mutacje dezaktywujące wiązanie GTP w genie kodującym RabF1 prowadzą do opóźnienia kwitnienia, choć mechanizm tego procesu nie został w pełni wyjaśniony [85]. Z kolei podwójny mutant w genach kodujących RabF2a i RabF2b jest letalny [86]. Nieznany jest też mechanizm letalności u wielokrotnych mutantów $\mathrm{w}$ genach kodujących RabD [87].

Bardzo istotnym rozwojowo procesem, u roślin i u zwierząt, jest programowana śmierć komórek - apoptoza. Także tutaj niezbędna jest aktywność odpowiednich białek Rab, z podrodziny RabG. Na poziomie komórki podrodzina RabG uczestniczy w transporcie do wakuoli oraz tworzeniu autofagosomów. Białka RabG3b pełnią funkcję w programowanej śmierci komórek związanej na przykład z tworzeniem naczyń drewna. Prekursory komórek drewna są żywe i w wyniku apoptozy trawią swoją zawartość, by stać się martwymi rureczkami o wzmocnionej wtórnej ścianie celulozowej, przystosowanymi do transportu wody. Ekspresja konstytutywnie aktywnego wariantu białka RabG3b przyspiesza procesy powstawania wiązek drewna u Arabidopsis i topoli $[88,89]$. Innym przykładem programowanej śmierci komórki w procesach rozwoju roślin jest degradacja komórek tapetum (warstwy odżywczej) w pylnikach. Mutacje w genie MON1, kodującym czynnik wymiany nukleotydu dla wszystkich białek RabG, opóźniają apoptozę komórek tapetum i tworzenie się prawidłowej zewnętrznej ściany komórkowej ziaren pyłku. W ostateczności prowadzi to do sterylności pyłku [90].

\section{PODSUMOWANIE}

Ostatnie lata przyniosły wiele odkryć dotyczących procesów transportu pęcherzykowego u roślin i jego aspektów regulacyjnych. Badania nad transportem pęcherzykowym, a w szczególności nad fizjologiczną rolą białek Rab na poziomie całych organizmów są interesujące także z biotechnologicznego i rolniczego punktu widzenia. Zmiany klimatyczne na Ziemi prowadzące do przedłużających się okresów suszy i pogarszająca się jakość gleb każą szukać odmian roślin o zwiększonej tolerancji na wysokie temperatury i zasolenie. Globalne rozprzestrzenianie się patogenów roślinnych w uprawach wskazuje kierunki badań dotyczących odporności na stres biotyczny. Poszukiwane są czynniki poprawiające wydajność upraw oraz trwałość plonów, aby uniknąć marnowania żywności. Dopuszczenie w wielu krajach do upraw roślin transgenicznych o pożądanych rolniczo cechach sprawia, że konieczne są też badania nad sterylnością pyłkową, aby zapobiec rozprzestrzenianiu się modyfikowanych ludzką ręką genotypów w populacjach dziko rosnących. Krzyżowanie roślin z takich przemysłowych upraw i ich niekontrolowane rozprzestrzenianie się mogłyby mieć tragiczne skutki dla zachowania różnorodności biologicznej ekosystemów. Badania nad białkami Rab u roślin wpisują się we wszystkie te trendy i wiedza o ich wynikach może być pomocna zarówno w prowadzeniu innych projektów naukowych, jak i budowaniu nowoczesnych, opartych na szerokiej wiedzy platform biotechnologicznych.

\section{LITERATURA}

1. Nielsen E (2020) The Small GTPase Superfamily in Plants: A Conserved Regulatory Module with Novel Functions. Annu Rev Plant Biol 71: $247-272$

2. Pfeffer SR (2017) Rab GTPases: master regulators that establish the secretory and endocytic pathways. Mol Biol Cell 28(6): 712-715

3. Shi W, Zeng Q, Kunkel BN, Running MP (2016) Arabidopsis Rab Geranylgeranyltransferases Demonstrate Redundancy and Broad Substrate Specificity in Vitro. J Biol Chem 291(3): 1398-1410

4. Elliott L i Kirchhelle C (2020) The importance of being edgy: cell geometric edges as an emerging polar domain in plant cells. J Microsc 278(3): 123-131

5. Bayer EM, Mongrand S, Tilsner J (2014) Specialized membrane domains of plasmodesmata, plant intercellular nanopores. Front Plant Sci 5: 507 
6. Gu F i Nielsen E (2013) Targeting and regulation of cell wall synthesis during tip growth in plants. J Integr Plant Biol 55(9): 835-846

7. Muller S (2019) Plant cell division - defining and finding the sweet spot for cell plate insertion. Curr Opin Cell Biol 60: 9-18

8. Tan X, Li K, Wang Z, Zhu K, Tan X, Cao J (2019) A Review of Plant Vacuoles: Formation, Located Proteins, and Functions. Plants (Basel) 8(9): 327

9. Renna L i Brandizzi F (2020) The mysterious life of the plant trans-Golgi network: advances and tools to understand it better. J Microsc 278(3): 154-163

10. Rutherford S i Moore I (2002) The Arabidopsis Rab GTPase family: another enigma variation. Curr Opin Plant Biol 5(6): 518-528

11. Sinclair R, Rosquete MR, Drakakaki G (2018) Post-Golgi Trafficking and Transport of Cell Wall Components. Front Plant Sci 9: 1784

12. Li R, Rodriguez-Furlan C, Wang J, van de Ven W, Gao T, Raikhel NV, Hicks GR (2017) Different Endomembrane Trafficking Pathways Establish Apical and Basal Polarities. Plant Cell 29(1): 90-108

13. Feraru E, Feraru MI, Asaoka R, Paciorek T, De Rycke R, Tanaka H, Nakano A, Friml J (2012) BEX5/RabA1b regulates trans-Golgi network-to-plasma membrane protein trafficking in Arabidopsis. Plant Cell 24(7): 3074-3086

14. Mayers JR, Hu T, Wang C, Cárdenas JJ, Tan Y, Pan J, Bednarek SY (2017) SCD1 and SCD2 Form a Complex That Functions with the Exocyst and RabE1 in Exocytosis and Cytokinesis. Plant Cell 29(10): 26102625

15. Hála M, Soukupová H, Synek L, Zárský V (2010) Arabidopsis RAB geranylgeranyl transferase beta-subunit mutant is constitutively photomorphogenic, and has shoot growth and gravitropic defects. Plant J 62(4): 615-627

16. Kirchhelle C, Chow CM, Foucart C, Neto H, Stierhof YD, Kalde M, Walton C, Fricker M, Smith RS, Jérusalem A, Irani N, Moore I (2016) The Specification of Geometric Edges by a Plant Rab GTPase Is an Essential Cell-Patterning Principle During Organogenesis in Arabidopsis. Dev Cell 36(4): 386-400

17. Preuss ML, Serna J, Falbel TG, Bednarek SY, Nielsen E (2004) The Arabidopsis Rab GTPase RabA4b localizes to the tips of growing root hair cells. Plant Cell 16(6): 1589-1603

18. Szumlanski AL i Nielsen E (2009) The Rab GTPase RabA4d regulates pollen tube tip growth in Arabidopsis thaliana. Plant Cell 21(2): 526544

19. Zhou Y, Yang Y, Niu Y, Fan T, Qian D, Luo C, Shi Y, Li S, An L, Xiang Y (2020) The Tip-Localized Phosphatidylserine Established by Arabidopsis ALA3 Is Crucial for Rab GTPase-Mediated Vesicle Trafficking and Pollen Tube Growth. Plant Cell 32(10): 3170-3187

20. Preuss ML, Schmitz AJ, Thole JM, Bonner HK, Otegui MS, Nielsen E (2006) A role for the RabA4b effector protein PI-4Kbeta1 in polarized expansion of root hair cells in Arabidopsis thaliana. J Cell Biol 172(7): 991-998

21. Camacho L, Smertenko AP, Pérez-Gómez J, Hussey PJ, Moore I (2009) Arabidopsis Rab-E GTPases exhibit a novel interaction with a plasma-membrane phosphatidylinositol-4-phosphate 5-kinase. J Cell Sci 122(Pt 23): 4383-4392

22. Stenzel I, Ischebeck T, König S, Hołubowska A, Sporysz M, Hause B, Heilmann I (2008) The type B phosphatidylinositol-4-phosphate 5-kinase 3 is essential for root hair formation in Arabidopsis thaliana. Plant Cell 20(1): 124-141

23. Orr RG, Furt F, Warner EL, Agar EM, Garbarino JM, Cabral SE, Dubuke ML, Butt AM, Munson M, Vidali L (2020) Rab-E and its interaction with myosin XI are essential for polarized cell growth. New Phytol. Online ahead of print

24. Jia PF, Xue Y, Li HJ, Yang WC (2018) Golgi-localized LOT regulates trans-Golgi network biogenesis and pollen tube growth. Proc Natl Acad Sci U S A 115(48): 12307-12312

25. Peng J, Ilarslan H, Wurtele ES, Bassham DC (2011) AtRabD2b and AtRabD2c have overlapping functions in pollen development and pollen tube growth. BMC Plant Biol 11: 25
26. Davis DJ, McDowell SC, Park E, Hicks G, Wilkop TE, Drakakaki G (2016) The RAB GTPase RABA1e localizes to the cell plate and shows distinct subcellular behavior from RABA2a under Endosidin 7 treatment. Plant Signal Behav 11(3): e984520

27. Berson $T$, von Wangenheim $D$, Takáč $T$, Šamajová $\mathrm{O}$, Rosero A, Ovečka M, Komis G, Stelzer EH, Šamaj J (2014) Trans-Golgi network localized small GTPase RabA1d is involved in cell plate formation and oscillatory root hair growth. BMC Plant Biol 14: 252

28. Qi X i Zheng H (2013) Rab-A1c GTPase defines a population of the trans-Golgi network that is sensitive to endosidin1 during cytokinesis in Arabidopsis. Mol Plant 6(3): 847-859

29. Qi X, Kaneda M, Chen J, Geitmann A, Zheng H (2011) A specific role for Arabidopsis TRAPPII in post-Golgi trafficking that is crucial for cytokinesis and cell polarity. Plant J 68(2): 234-248

30. Chow CM, Neto H, Foucart C, Moore I (2008) Rab-A2 and Rab-A3 GTPases define a trans-golgi endosomal membrane domain in Arabidopsis that contributes substantially to the cell plate. Plant Cell 20(1): 101-123

31. Lunn D, Gaddipati SR, Tucker GS, Lycett GW (2013) Null mutants of individual RABA genes impact the proportion of different cell wall components in stem tissue of Arabidopsis thaliana. PLoS One 8(10): e75724

32. He M, Lan M, Zhang B, Zhou Y, Wang Y, Zhu L, Yuan M, Fu Y (2018) Rab-H1b is essential for trafficking of cellulose synthase and for hypocotyl growth in Arabidopsis thaliana. J Integr Plant Biol 60(11): 1051 1069

33. Rivero C, Traubenik S, Zanetti ME, Blanco FA (2019) Small GTPases at plant biotic interactions. Small GTPases 10(5):350-360

34. Beck M, Zhou J, Faulkner C, MacLean D, Robatzek S (2012) Spatio-temporal cellular dynamics of the Arabidopsis flagellin receptor reveal activation status-dependent endosomal sorting. Plant Cell 24(10): 4205-4219

35. Bourdais G, McLachlan DH, Rickett LM, Zhou J, Siwoszek A, Häweker H, Hartley M, Kuhn H, Morris RJ, MacLean D, Robatzek S (2019) The use of quantitative imaging to investigate regulators of membrane trafficking in Arabidopsis stomatal closure. Traffic 20(2): 168-180

36. Tomczyńska I, Stumpe M, Mauch F (2018) A conserved RxLR effector interacts with host RabA-type GTP-ases to inhibit vesicle-mediated secretion of antimicrobial proteins. Plant J 95(2):187-203

37. Ellinger D, Glöckner A, Koch J, Naumann M, Stürtz V, Schütt K, Manisseri C, Somerville SC, Voigt CA (2014) Interaction of the Arabidopsis GTPase RabA4c with its effector PMR4 results in complete penetration resistance to powdery mildew. Plant Cell 26(7): 3185-3200

38. Antignani V, Klocko AL, Bak G, Chandrasekaran SD, Dunivin T, Nielsen E (2015) Recruitment of PLANT U-BOX13 and the PI4Kbeta1/ beta2 phosphatidylinositol- 4 kinases by the small GTPase RabA4B plays important roles during salicylic acid-mediated plant defense signaling in Arabidopsis. Plant Cell 27(1): 243-261

39. Nielsen ME, Jürgens G, Thordal-Christensen H (2017) VPS9a Activates the Rab5 GTPase ARA7 to Confer Distinct Pre- and Postinvasive Plant Innate Immunity. Plant Cell 29(8): 1927-1937

40. Inada N, Betsuyaku S, Shimada TL, Ebine K, Ito E, Kutsuna N, Hasezawa S, Takano Y, Fukuda H, Nakano A, Ueda T (2016) Modulation of Plant RAB GTPase-Mediated Membrane Trafficking Pathway at the Interface Between Plants and Obligate Biotrophic Pathogens. Plant Cell Physiol 57(9): 1854-1864

41. Ostertag M, Stammler J, Douchkov D, Eichmann R, Hückelhoven R (2013) The conserved oligomeric Golgi complex is involved in penetration resistance of barley to the barley powdery mildew fungus. Mol Plant Pathol 14(3): 230-240

42. Kwon SI, Cho HJ, Kim SR, Park OK (2013) The Rab GTPase RabG3b positively regulates autophagy and immunity-associated hypersensitive cell death in Arabidopsis. Plant Physiol 161(4): 1722-1736

43. Jiang Z, Wang H, Zhang G, Zhao R, Bie T, Zhang R, Gao D, Xing L, Cao A (2017) Characterization of a small GTP-binding protein gene TaRab18 from wheat involved in the stripe rust resistance. Plant Physiol Biochem 113: 40-50 
44. Roos J, Bejai S, Oide S, Dixelius C (2014) RabGAP22 is required for defense to the vascular pathogen Verticillium longisporum and contributes to stomata immunity. PLoS One 9(2): e88187

45. Kim WY, Kim CY, Cheong NE, Choi YO, Lee KO, Lee SH, Park JB, Nakano A, Bahk JD, Cho MJ, Lee SY (1999) Characterization of two fungal-elicitor-induced rice cDNAs encoding functional homologues of the rab-specific GDP-dissociation inhibitor. Planta 210(1): 143-149

46. Blanco FA, Meschini EP, Zanetti ME, Aguilar OM (2009) A small GTPase of the Rab family is required for root hair formation and preinfection stages of the common bean-Rhizobium symbiotic association. Plant Cell 21(9): 2797-2810

47. Dalla Via V, Traubenik S, Rivero C, Aguilar OM, Zanetti ME, Blanco FA (2017) The monomeric GTPase RabA2 is required for progression and maintenance of membrane integrity of infection threads during root nodule symbiosis. Plant Mol Biol 93(6): 549-562

48. Haupt S, Cowan GH, Ziegler A, Roberts AG, Oparka KJ, Torrance L (2005) Two plant-viral movement proteins traffic in the endocytic recycling pathway. Plant Cell 17(1): 164-181

49. Huang YP, Hou PY, Chen IH, Hsu YH, Tsai CH, Cheng CP (2020) Dissecting the role of a plant-specific Rab5 small GTPase NbRabF1 in Bamboo mosaic virus infection. J Exp Bot 2020 Dec 31;71(22):6932-6944

50. Liu Q, Deng S, Liu B, Tao Y, Ai H, Liu J, Zhang Y, Zhao Y, Xu M (2020) A helitron-induced RabGDIalpha variant causes quantitative recessive resistance to maize rough dwarf disease. Nat Commun 11(1): 495

51. Xu K i Nagy PD (2016) Enrichment of Phosphatidylethanolamine in Viral Replication Compartments via Co-opting the Endosomal Rab5 Small GTPase by a Positive-Strand RNA Virus. PLoS Biol 14(10): e2000128

52. Agbeci M, Grangeon R, Nelson RS, Zheng H, Laliberté JF (2013) Contribution of host intracellular transport machineries to intercellular movement of turnip mosaic virus. PLoS Pathog 9(10): e1003683

53. Speth EB, Imboden L, Hauck P, He SY (2009) Subcellular localization and functional analysis of the Arabidopsis GTPase RabE. Plant Physiol 149(4): 1824-1837

54. Asaoka R, Uemura T, Ito J, Fujimoto M, Ito E, Ueda T, Nakano A (2013) Arabidopsis RABA1 GTPases are involved in transport between the trans-Golgi network and the plasma membrane, and are required for salinity stress tolerance. Plant J 73(2): 240-249

55. Peng X, Ding X, Chang T, Wang Z, Liu R, Zeng X, Cai Y, Zhu Y (2014) Overexpression of a Vesicle Trafficking Gene, OsRab7, enhances salt tolerance in rice. ScientificWorldJournal 2014: 483526

56. Li S, Xu C, Yang Y, Xia G (2010) Functional analysis of TaDi19A, a salt-responsive gene in wheat. Plant Cell Environ 33(1): 117-129

57. Baral A, Irani NG, Fujimoto M, Nakano A, Mayor S, Mathew MK (2015) Salt-induced remodeling of spatially restricted clathrin-independent endocytic pathways in Arabidopsis root. Plant Cell 27(4): 1297-1315

58. Rajagopal D i Mathew MK (2020) Role of Arabidopsis RAB5 GEF vps9a in maintaining potassium levels under sodium chloride stress. Plant Direct 4(10): e00273

59. Tripathy MK, Tiwari BS, Reddy MK, Deswal R, Sopory SK (2017) Ectopic expression of PgRab7 in rice plants (Oryza sativa L.) results in differential tolerance at the vegetative and seed setting stage during salinity and drought stress. Protoplasma 254(1): 109-124

60. Takano J, Miwa K, Yuan L, von Wirén N, Fujiwara T (2005) Endocytosis and degradation of BOR1, a boron transporter of Arabidopsis thaliana, regulated by boron availability. Proc Natl Acad Sci U S A 102(34): 12276-12281

61. Yang A i Zhang WH (2016) A Small GTPase, OsRab6a, is Involved in the Regulation of Iron Homeostasis in Rice. Plant Cell Physiol 57(6): $1271-1280$

62. Lunn D, Phan TD, Tucker GA, Lycett GW (2013) Cell wall composition of tomato fruit changes during development and inhibition of vesicle trafficking is associated with reduced pectin levels and reduced softening. Plant Physiol Biochem 66: 91-97
63. Lu C, Zainal Z, Tucker GA, Lycett GW (2001) Developmental abnormalities and reduced fruit softening in tomato plants expressing an antisense Rab11 GTPase gene. Plant Cell 13(8): 1819-1833

64. Lawson T, Mayes S, Lycett GW, Chin CF (2018) Plant Rabs and the role in fruit ripening. Biotechnol Genet Eng Rev 34(2): 181-197

65. Falchi R, Cipriani G, Marrazzo T, Nonis A, Vizzotto G, Ruperti B (2010) Identification and differential expression dynamics of peach small GTPases encoding genes during fruit development and ripening. J Exp Bot 61(10): 2829-2842

66. Briegas B, Corbacho J, Parra-Lobato MC, Paredes MA, Labrador J, Gallardo M, Gomez-Jimenez MC (2020) Transcriptome and Hormone Analyses Revealed Insights into Hormonal and Vesicle Trafficking Regulation among Olea europaea Fruit Tissues in Late Development. Int J Mol Sci 21(14)

67. Fukuda M, Wen L, Satoh-Cruz M, Kawagoe Y, Nagamura Y, Okita TW, Washida H, Sugino A, Ishino S, Ishino Y, Ogawa M, Sunada M, Ueda T, Kumamaru T (2013) A guanine nucleotide exchange factor for Rab5 proteins is essential for intracellular transport of the proglutelin from the Golgi apparatus to the protein storage vacuole in rice endosperm. Plant Physiol 162(2): 663-674

68. Ren Y, Wang Y, Pan T, Wang Y, Wang Y, Gan L, Wei Z, Wang F, Wu M, Jing R, Wang J, Wan G, Bao X, Zhang B, Zhang P, Zhang Y, Ji Y, Lei C, Zhang X, Cheng Z, Lin Q, Zhu S, Zhao Z, Wang J, Wu C, Qiu L, Wang H, Wan J (2020) GPA5 Encodes a Rab5a Effector Required for Post-Golgi Trafficking of Rice Storage Proteins. Plant Cell 32(3): 758777.

69. Sakurai HT, Inoue T, Nakano A, Ueda T (2016) ENDOSOMAL RAB EFFECTOR WITH PX-DOMAIN, an Interacting Partner of RAB5 GTPases, Regulates Membrane Trafficking to Protein Storage Vacuoles in Arabidopsis. Plant Cell 28(6): 1490-1503

70. Bottanelli F, Foresti O, Hanton S, Denecke J (2011) Vacuolar transport in tobacco leaf epidermis cells involves a single route for soluble cargo and multiple routes for membrane cargo. Plant Cell 23(8): 3007-3025

71. Wang Y, Ren Y, Liu X, Jiang L, Chen L, Han X, Jin M, Liu S, Liu F, Lv J, Zhou K, Su N, Bao Y, Wan J (2010) OsRab5a regulates endomembrane organization and storage protein trafficking in rice endosperm cells. Plant J 64(5): 812-824

72. Tsutsui T, Nakano A, Ueda T (2015) The Plant-Specific RAB5 GTPase ARA6 is Required for Starch and Sugar Homeostasis in Arabidopsis thaliana. Plant Cell Physiol 56(6): 1073-1083

73. Tyler AM, Bhandari DG, Poole M, Napier JA, Jones HD, Lu C, Lycett GW (2015) Gluten quality of bread wheat is associated with activity of RabD GTPases. Plant Biotechnol J 13(2): 163-176

74. Shirakawa M, Ueda H, Shimada T, Kohchi T, Hara-Nishimura I (2014) Myrosin cell development is regulated by endocytosis machinery and PIN1 polarity in leaf primordia of Arabidopsis thaliana. Plant Cell 26(11): 4448-4461

75. Shirley NJ, Aubert MK, Wilkinson LG, Bird DC, Lora J, Yang X, Tucker MR (2019) Translating auxin responses into ovules, seeds and yield: Insight from Arabidopsis and the cereals. J Integr Plant Biol 61(3): 310336

76. Le J, Liu XG, Yang KZ, Chen XL, Zou JJ, Wang HZ, Wang M, Vanneste S, Morita M, Tasaka M, Ding ZJ, Friml J, Beeckman T, Sack F (2014) Auxin transport and activity regulate stomatal patterning and development. Nat Commun 5: 3090

77. Rodriguez-Villalon A, Gujas B, Kang YH, Breda AS, Cattaneo P, Depuydt S, Hardtke CS (2014) Molecular genetic framework for protophloem formation. Proc Natl Acad Sci U S A 111(31): 11551-11556

78. Rojek J, Tucker MR, Pinto SC, Rychłowski M, Lichocka M, Soukupova H, Nowakowska J, Bohdanowicz J, Surmacz G, Gutkowska M (2020) Rab-dependent vesicular traffic affects female gametophyte development in Arabidopsis. J Exp Bot. Online ahead of print

79. Naramoto S, Nodzyłski T, Dainobu T, Takatsuka H, Okada T, Friml J, Fukuda H (2014) VAN4 encodes a putative TRS120 that is required for normal cell growth and vein development in Arabidopsis. Plant Cell Physiol 55(4): 750-763

80. Gutkowska M, Wnuk M, Nowakowska J, Lichocka M, Stronkowski MM, Swiezewska E (2015) Rab geranylgeranyl transferase beta sub- 
unit is essential for male fertility and tip growth in Arabidopsis. J Exp Bot 66(1): 213-224

81. Thole JM, Perroud PF, Quatrano RS, Running MP (2014) Prenylation is required for polar cell elongation, cell adhesion, and differentiation in Physcomitrella patens. Plant J 78(3): 441-451

82. Ahn CS, Han JA, Pai HS (2013) Characterization of in vivo functions of Nicotiana benthamiana RabE1. Planta 237(1): 161-172

83. Grebe M, Xu J, Möbius W, Ueda T, Nakano A, Geuze HJ, Rook MB, Scheres B (2003) Arabidopsis sterol endocytosis involves actin-mediated trafficking via ARA6-positive early endosomes. Curr Biol 13(16): 1378-1387

84. Goh T, Uchida W, Arakawa S, Ito E, Dainobu T, Ebine K, Takeuchi M, Sato K, Ueda T, Nakano A (2007) VPS9a, the common activator for two distinct types of Rab5 GTPases, is essential for the development of Arabidopsis thaliana. Plant Cell 19(11): 3504-3515

85. Ebine K, Uemura T, Nakano A, Ueda T (2012) Flowering time modulation by a vacuolar SNARE via FLOWERING LOCUS C in Arabidopsis thaliana. PLoS One 7(7): e42239
86. Inoue T, Kondo Y, Naramoto S, Nakano A, Ueda T (2013) RAB5 activation is required for multiple steps in Arabidopsis thaliana root development. Plant Cell Physiol 54(10): 1648-1659

87. Pinheiro H, Samalova M, Geldner N, Chory J, Martinez A, Moore I (2009) Genetic evidence that the higher plant Rab-D1 and Rab-D2 GTPases exhibit distinct but overlapping interactions in the early secretory pathway. J Cell Sci 122(Pt 20):3749-58

88) Kwon SI, Cho HJ, Jung JH, Yoshimoto K, Shirasu K, Park OK (2010) The Rab GTPase RabG3b functions in autophagy and contributes to tracheary element differentiation in Arabidopsis. Plant J 64(1): 151-164

89. Kwon SI, Cho HJ, Lee JS, Jin H, Shin SJ, Kwon M, Noh EW, Park OK (2010) Overexpression of constitutively active Arabidopsis RabG3b promotes xylem development in transgenic poplars. Plant Cell Environ 34(12): 2212-24.

90. Cui Y, Zhao Q, Xie HT, Wong WS, Wang X, Gao C, Ding Y, Tan Y, Ueda T, Zhang Y, Jiang L (2017) MONENSIN SENSITIVITY1 (MON1)/CALCIUM CAFFEINE ZINC SENSITIVITY1 (CCZ1)-Mediated Rab7 Activation Regulates Tapetal Programmed Cell Death and Pollen Development. Plant Physiol 173(1): 206-218

\section{The functions of Rab proteins in plants - from cellular to organismal level}

\section{Małgorzata Gutkowska ${ }^{\varpi}$, Marta Hoffman-Sommer, Paweł Jakub Kubski}

Institute of Biochemistry and Biophysics, PAS, Warszawa

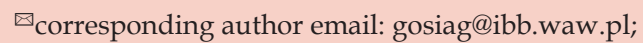

Keywords: Rab protein, vesicle transport, plant, Arabidopsis

\section{SUMMARY}

Rab proteins are necessary for membrane fusion and fission and as such are key regulators of intracellular transport in eukaryotic cells. They also control other aspects of cell functioning, including the cytoskeleton rearrangements, determination of cell polarity or signal transduction. Rab proteins exert their control both indirectly, because they decide whether all necessary proteins and other cargo reach their correct destinations in the cell, and directly, through interactions of their active forms with effector proteins. Therefore, the results of Rab dysfunctions manifest themselves on all levels of biological organization - from cells, through tissues and organs, to whole organisms. In plants, Rab-dependent processes are important for cell architecture, differentiation, reactions to biotic and abiotic stress, as well as for the efficiency of agricultural production. 